\title{
Neoadjuvant Chemotherapy in Gastric Cancer
}

\author{
위암에서의 선행화학요법
}

\section{Department of Surgery, Soonchunhyang University Colleage of Medicine Moon-Soo Lee, M.D.}

순천향대학교 의과대학 외과학교실 이 문 수

서

위암의 발생 빈도와 사망률은 감소하고 있으나 위암은 여전히 우리나라에서 발생빈도가 높은 암으로서 항암 화학요법에 잘 반응 하지 않는 암종으로 알려져 있으며, 조기 위암인 경우는 약 $50 \%$ 정도로 아직까지 진단시 진행성 위암으로 발견되는 경우가 많다. 위암의 치료는 현재 일차적 병소를 포함한 위절제와 주변 림프 절 절제술이 유일한 근치적 치료법으로서 림프절 절제의 범위는 아직 논란이 있으나 D2 림프절제술이 표준적인 수술 방법으로 자 리잡고 있다. 그러나 이러한 근치적 절제술 후에도 재발율은 50 70\%로 보고되고 있으며 특히 진행성 위암의 경우는 조기 위 암과 비교하여 더욱 예후가 불량하다. 이에 위암환자의 치료 성 적을 향상시키기 위한 많은 노력과 함께 최근 위암 치료에 대한 다학제적 치료(multimodal treatment)에 관심이 집중되고 있다. 다학제적 치료는

1) 수술 후 화학요법 또는 방사선 요법

2) 수술 전 선행화학요법과 수술 후 화학요법

3) 방사선 요법을 병행하는 수술 전 선행화학요법 등이 있다. ${ }^{1 \sim 6)}$ 수술 전 선행화학요법은 1989년 Wilke 등에 의해 절제가 불 가능한 위암 환자를 대상으로 술전 화학요법을 시행한 연구에서 향상된 치료 효과가 처음 보고된 이후 최근의 3상 연구에 이르기 까지 그 연구가 활발히 진행되고 있다. 이에 본문에서는 위암에서 의 수술 전 화학요법에 관한 임상연구 결과의 분석을 토대로 술전 화학요법의 의미를 알아보고, 술전 화학요법이 향후 다학제적 위 암 치료의 한 방법으로 자리잡기 위한 연구의 방향을 설정하는데 도움이 되고자 한다.

책임저자 : 이문수

충남 천안시 동남구 순천향 2 길 8 (봉명동 23-20) 순천향대학교 부속 천안병원 외과 Tel : 041-570-3632, Fax: 041-571-0129, E- mail : msslee@schca.ac.kr 접수일 : 2008년 10월 4일 ; 게재승인일 : 2008년 10월 29일

\section{본 론}

수술 전 선행화학요법은 이미 식도암이나 직장암의 경우 재발 율을 감소시키고 생존율을 향상시키며, 수술 후 합병증 및 이환율 이나 사망률에도 영향을 주지 않는다고 보고되고 있다. 이러한 수 술 전 선행화학요법의 이론적 배경은 다음과 같다. 첫째, 수술전 발견하지 못한 미세전이를 조기에 치료할 수 있다. 근치적 절제술 후 재발에 영향을 미치는 중요한 인자 중 하나인 미세전이를 수 술 전 항암제에 조기에 노출시킴으로써 치료의 근치도를 높일 수 있다는 점이다. 둘째, 수술 전 원발종양을 축소시킴으로써 근치적 절제율을 향상 시킬 수 있다. 셋째, 조기에 화학요법을 시행하기 때문에 환자의 전신상태가 양호하고 충분한 용량을 투여할 수 있 어 원발종양의 반응률을 높일 수 있으며 수술 후 화학요법과 비교 하여 환자의 순응도가 좋다. 넷째, 화학요법의 생체내 감수성을 평가할 수 있으므로 술후 항암제 선택의 정보를 제공할 수 있다. 다섯째, 술전 화학요법에 대한 반응으로 술후 환자의 예후를 예측 할 수 있다. 그러나 이러한 장점에도 불구하고 아직까지 위암에서 수술 전 선행화학요법이 표준치료로 적용되지 못하고 있다. 그 이 유로는 첫째, 수술 전 정확한 병기의 결정이 어려워 초기 위암 환 자에게 불필요하게 선행화학요법을 시행할 수 있으며 둘째, 선택 된 술전 화학요법에 반응하지 않아 수술이 지연되는 결과를 가져 옴으로써 근치적 절제가 불가능해질 위험이 있다. 셋째, 화학요법 과 관련된 독성으로 술후 합병증이 증가할 가능성이 있다. 넷째, 선행화학요법에 반응이 좋은 경우 종양의 경계가 불분명하게 될 가능성이 있어 부적절한 축소 수술이 될 가능성이 있다는 점이 그 단점으로 지적되고 있다.

현재까지의 2 상 연구(Phase II study)에서는 $19 \sim 58 \%$ 의 술후 이환율과 0 5.3\%의 사망율, 30 80\%의 근치적 절제율과 15 개 월에서 52 개월까지의 향상된 중앙 생존기간이 보고되었는데, 이 러한 다양한 치료성적은 각각의 연구마다 수술 전 진단방법, 대 
Table 1. Neoadjuvant Treatment for Locally Advanced Gastric Cancer: Phase II Trials

\begin{tabular}{|c|c|c|c|c|c|c|c|c|c|}
\hline Trial & $\begin{array}{c}\text { Diagnostic } \\
\text { methods }\end{array}$ & Stage & Regimen & No. of patients & $\begin{array}{l}\text { R0 rate } \\
(\%)\end{array}$ & $\begin{array}{l}\text { PCR } \\
(\%)\end{array}$ & $\begin{array}{l}\text { Morbiddity } \\
(\%)\end{array}$ & $\begin{array}{l}\text { Mortality } \\
(\%)\end{array}$ & $\begin{array}{l}\text { Med. survival } \\
\text { (M) }\end{array}$ \\
\hline Wilke 1989 & laparotomy & Unresectable & EAP & 34 & 29 & 15 & NS & NS & 18 \\
\hline Kelsen 1996 & EUS & $\begin{array}{l}\text { T3-4, N any } \\
\text { T2N1-2 }\end{array}$ & $\begin{array}{l}\text { FAMTX } \rightarrow \\
\text { ipFP+iv5FU }\end{array}$ & 56 & 61 & 0 & 34 & 4 & 15.3 \\
\hline Crookes 1997 & $\mathrm{CT}+$ /or GFS & Resectable & $\begin{array}{l}\mathrm{FP} \rightarrow \\
\text { Ip FUDR /CDDP }\end{array}$ & 59 & 68 & 8 & 23 & 3.6 & 52 \\
\hline Ajani 1999 & $\begin{array}{l}\text { EUS+ } \\
\text { laparoscopy }\end{array}$ & $\begin{array}{l}\text { Resectable } \\
>\mathrm{T} 1, \geq 2 \mathrm{~cm}\end{array}$ & 5 -FU/ INF ${ }_{\alpha} 2 b$ & 30 & 83 & 7 & 24 & 0 & 30 \\
\hline Schuhmacher 2001 & $\begin{array}{l}\text { EUS+ } \\
\text { laparoscopy }\end{array}$ & IIIIIV & EAP & 42 & 74 & 0 & 44 & 2.8 & 19.1 \\
\hline Ott 2003 & $\begin{array}{l}\text { CT+GFS+ } \\
\text { laparoscopy }\end{array}$ & $\begin{array}{l}\text { T3-4, N+ } \\
\text { M0 }\end{array}$ & FLP & 49 & 65 & 0 & 19 & 0 & 29 \\
\hline Persiani 2005 & & Resectable & $\begin{array}{l}\mathrm{EEP} \rightarrow \\
\mathrm{ECF}\end{array}$ & 33 & 82 & 3 & NS & NS & NS \\
\hline Brenner 2006 & $\begin{array}{l}\text { EUS+ } \\
\text { laparoscopy }\end{array}$ & $\begin{array}{l}\text { T2N1-2/ } \\
\text { T3-4N any }\end{array}$ & $\begin{array}{l}\mathrm{FP} \rightarrow \\
\mathrm{ipFUdR/LV}\end{array}$ & 38 & 84 & 0 & 29 & 0 & 30.3 \\
\hline
\end{tabular}

$\mathrm{PCR}=$ pathologic complete response; EUS=Endoscopic ultrasound; CT=Computed tomography;

GFS=Gastrofiberoscopy; EAP=etoposide, adriamycin, cisplatin; FAMTX=5-FU, adriamycin, methotrexate;

ip=intraperitoneal; $\mathrm{FP}=5-\mathrm{FU}$, cisplatin; iv=intravenous; $5-\mathrm{FU}=5$-fluorouracil; FUDR=floxuridine;

$\mathrm{INF}=$ interferon; FLP=5-FU, leukovorin, cisplatin; EEP=epidoxorubicin, etoposide, cisplatin; LV=leukovorin

상 환자의 설정, 사용된 항암제의 종류, 항암제 투여 방법, 수술 방법등이 각 연구마다 차이가 있었기 때문으로 판단된다(Table. 1).

3상 연구(Phase III study)를 검토해보면 1997년 Dutch trial에서 원격전이가 없고 수술적 절제가 가능한 위암 환자를 대 상으로 선행화학요법군과 수술 단독 시행군을 비교한 결과 근치 적 절제율 및 수술 후 병기에서 장점을 발견할 수 없었고 오히려 선행화학요법군에서 5 년 생존율이 낮은 경향을 나타내었다. 그러 나 이 연구는 저조한 환자 등록율로 30 개월간 59 명의 환자 만이 등록되었고 조기 종료되어서 결과의 의미를 평가하는데 어려움이 있다. ${ }^{8)}$ 그러나, 궁극적인 선행화학요법의 효과 판정을 위해서는 다수의 환자를 대상으로 대조군과의 3 상 연구가 필수적이며, 최 근 2 개의 대규모 3 상 연구 결과가 발표되었다. 2006년 영국의 MAGIC trial(Fig. 1)은 2기 이상의 환자 503명을 대상으로 진 행한 대규모 연구결과로 수술 전, 후 화학요법군(ECF[epirubicin+cisplatin+5-fluorouracil])과 수술 단독군과의 비교에 서 술후 이환율과 사망률이 두 군간 차이가 없었고, 수술 후 병 리학적 결과가 절제 종양의 크기 $(3 \mathrm{~cm}$ vs. $5 \mathrm{~cm}, \mathrm{P}<0.001)$, T1-2 환자의 비율 $(51.7 \%$ vs. $36.8 \%, \mathrm{P}=0.002)$ 과 $\mathrm{N} 0-1$ 환자 의 비율 $(84.4 \%$ vs. $70.5 \%, \mathrm{P}=0.01)$ 이 화학요법군에서 통계적 으로 의미있게 높았으며, 5 년 생존율( $36.3 \%$ vs. $23.0 \%$, $\mathrm{P}=0.009)$ 에서도 화학요법군이 더 향상된 결과로 보고되었다. ${ }^{9}$ 이러한 결과를 바탕으로 유럽에서는 수술 전, 후 화학요법을 표준 치료로 적용하기도 하였으나 이 연구에서는 D2 림프절 절제술이
$41 \%$ 에서만 시행되었고 D1 림프절 절제술이 $19 \%$, 절제범위에 대 한 언급이 없는 경우도 있어 D2 림프절 절제술을 표준치료로 하 고 있는 한국과는 차이가 있으며 외과의사의 숙련도 또한 문제로 지적될 수 있다. 또한 수술 단독군의 근치적 절제율이 $66.4 \%, 5$ 년 생존율 $23 \%$ 로 $80 \%$ 내외의 근치적 절제율과 $60 \%$ 정도의 5 년 생존율을 보고하고 있는 한국과 차이를 보이고 있으며, 대상 환자 중 식도 및 식도접합부 암의 비율이 한국에 비해 높고 수술 전, 후 화학요법을 시행한 연구로 생존율 향상이 선행화학요법에 의한 결과 만은 아닐 수 있다는 의문점을 가질 수 있다. 아울러 수술 단 독군에서 $\mathrm{T} 1$ 병기 환자가 $8.3 \%$ 포함되어 있어 수술 전, 후 화학 요법군에도 $\mathrm{T} 1$ 병기 환자가 포함되어 수술만으로도 우수한 생존 율이 기대되는 조기암 환자가 불필요한 항암제 독성에 노출되었 을 가능성도 유추해 볼 수 있다. 이렇듯 지적된 몇가지 문제점을 고려한다면 이 결과를 그대로 임상에 적용하기에는 무리가 있다.

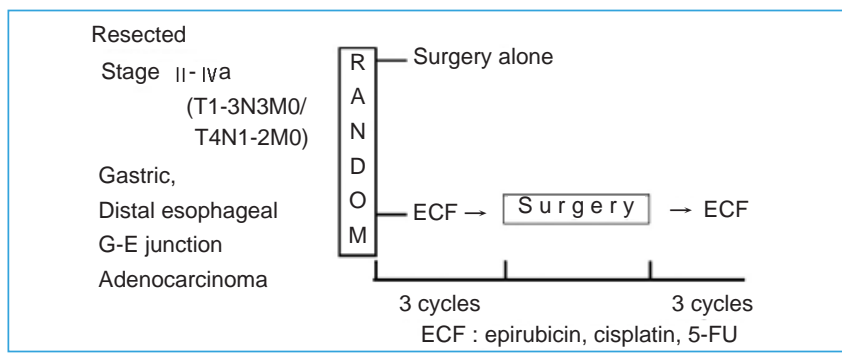

Fig. 1. MAGIC trial: study design. 
그러나, 이러한 몇가지 문제점에도 선행화학요법군이 수술 단독 군에 비하여 절제시 종양의 크기가 작았고, 초기의 $\mathrm{T}, \mathrm{N}$ 병기의 비율이 높아 상당 수의 병기하강이 일어났음을 시사하고 국소 재 발과 원격 전이의 감소와 함께 생존율 향상을 보였다는 점에서 Magic trial은 위암에서 선행화학요법의 역할을 제시한 중요한 연구로 평가된다. 또한 2007년 프랑스 FFCD group의 FNLCC 94012/FFCD 9703 trial이 발표되었다. ${ }^{10)}$ 이 연구는 2기 이상 의 하부 식도와 위암 환자 224 명을 대상으로 수술 전, 후 화학요 법군(FUP[5-fluorouracil + cisplatin])과 수술 단독군을 비 교하여 수술 이환율과 사망률에서 두 군간 차이가 없었고, 근치적 절제율(R0 resection rate)이 화학요법군에서 의미있게 높았으 며 $(87 \%$ vs. $74 \%, \mathrm{P}=0.04)$, 무 진행 생존기간과 5년 생존율 (40\% vs. $25 \%, 17$ vs. $34 \%)$ 도 화학요법군에서 더 향상된 결과 를 발표하였다.

한편 한국에서 시행된 3상 임상연구로는 $\mathrm{KCCH}$ trial이 1996 년 처음으로 보고되었다. 이 연구는 107명의 위암 환자를 대상으 로 선행화학요법군(PEF[cisplatin + etoposide + 5- fluorouracil])과 수술 단독군과 비교한 결과 위 절제율( $98 \%$ vs $87 \%$, $\mathrm{P}=0.04)$ 과 근치적 절제율( $81 \%$ vs $61 \%, \mathrm{P}=0.03)$ 에서 선행화학 요법군이 유의한 장점이 있었고, 수술후 병기가 유의하게 병기하 강이 되었으나 전체 생존율은 두 군간 차이가 없었으며 무병 생존 율은 오히려 선행화학요법군이 오히려 더 낮은 결과로 발표되었다. ${ }^{11}$ 선행화학요법은 환자의 병기를 낮추어 근치율을 높이고 궁극적 으로 생존율을 높이는데 목적이 있지만 이러한 목적에 적합한 화 학요법 치료제가 선택되어도 치료제의 독성 발현의 조절이 가능 하고 술후 이환율 및 사망률 증가가 없어야 화학요법 치료제로서 의 유용성이 인정되며, 이러한 화학요법 치료제의 효과를 극대 화 할 수 있는 적정 투여계획의 정립이 선행화학요법에서 매우 중 요한 고려사항이다. ${ }^{12)}$ 이에 최근 진행되고 있는 임상연구로는 과 거 5-FU 또는 cisplatin 병합 화학요법에서 oxaliplatin, capecitabine, bevacizumab등 다양한 약제를 적용시킨 임상 연구가 시도되고 있는데, ECF로 시행한 MAGIC trial 에 이어 epirubicin, oxaliplatin, capecitabin을 병합한 군과 여기에 bevacizumab을 추가한 regimen을 적용시킨 군과 비교 연구를 하고 있는 MAGIC B trial이 진행되고 있고, 수술 전 ECX(epirubicin, oxaliplatin, capecitabine) 화학요법을 시행하고 수술 후 다시 ECX 화학요법을 병행한 군과 Epirubicin을 빼고 CX 화학요법과 방사선 요법을 시행한 그룹간의 비교 연구인 CRITICS도 진행 중이며, 수술전 doxetaxel, cisplatin, 5-FU로 선 행화학요법만 시행한 후 수술을 받은 그룹과 선행항암화학요법 없이 수술 후 동일 약제로 항암화학요법을 받은 그룹간의 비교로 선행화학요법의 효과를 알아보기 위한 스위스의 SAKK 43/49 trial 등 매우 다양한 3상 연구가 진행 중이다(Fig. 2). 그러나, 이러한 선행화학요법을 시행하기 위한 필수 요건으로는 수술전 병기결정의 정확도를 높이기 위한 노력이 무엇보다도 중요하다. $\mathrm{T}$ 병기의 결정은 내시경 초음파가 $79 \sim 92 \%$ 의 정확도로 가장 나 은 진단방법이며, $\mathrm{N}$ 병기는 내시경 초음파의 경우 $\mathrm{N} 1$ 의 진단은 비교적 유용하나 N2의 진단에는 한계가 있고 현재로서는 MDCT 나 $\mathrm{PET}-\mathrm{CT}$ 의 개발에도 불구하고 정확한 N 병기 결정에는 아직 어려움이 있다. $\mathrm{M}$ 병기는 컴퓨터 단층 촬영을 이용하여 원격전이 를 확인하는데 $65 \sim 72 \%$ 의 정확도가 있으며, 최근에는 복강경을 이용하여 복막전이, 장막침범, 주위 장기침범등을 발견하거나 복 강내 세척액의 검사도 가능하게 되었다. 따라서 한가지 방법이 아 니라 EUS나 CT, 진단적 복강경 등을 모두 이용하여 좀 더 정확 한 술전 병기결정을 위해 노력하여야 하며, 이를 통해 선행화학요 법을 시행할 대상환자의 선정에 신중함을 기해야 한다. 아울러 위 암의 치료에 대한 새로운 개념으로서 다학제적인 치료가 발전됨 에 따라 치료방침 결정 및 적정 치료계획 설정을 위해 외과,
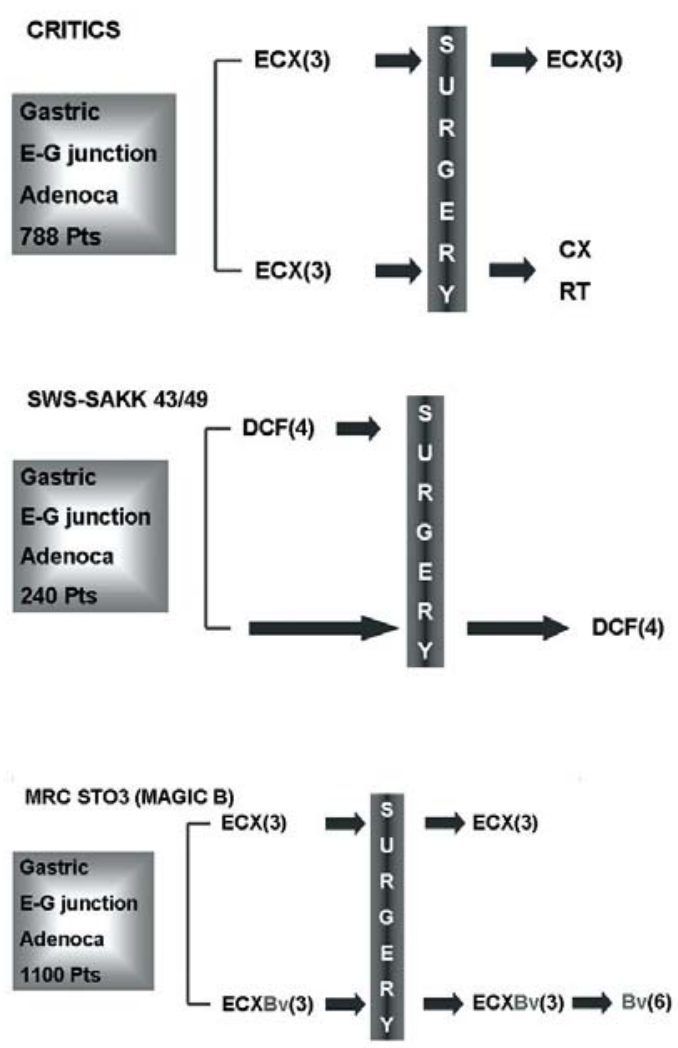

DCF : docetaxel, cisplatin, 5-FU ECX : epirubicin, oxaliplatin, capecitabine RT : radiotherapy Bv : bevacizumab

Fig. 2. Phase III study of neoadjuvant chemotherapy (ongoing study). 
소화기 내과, 혈액종양 내과, 영상의학과, 방사선 종양학과등이 참여하는 협진 팀제의 운영 또한 필요하다.

선행화학요법의 효과에 대한 반응 평가는 크게 임상적 평가와 조직학적 평가로 나뉘는데 임상적 평가로는 내시경을 이용해 종 양의 크기 변화를 보고, 내시경 초음파와 컴퓨터 단층촬영을 이용 해 T병기 및 종양의 변화와 $\mathrm{N}$ 병기의 변화를 관찰하는 것인데 이 는 신뢰도가 높지않은 평가 방법으로 알려져 있으며, Becker의 병리조직학적 평가에 따른 분류를 이용하고 있다. 화학요법은 종 양의 외장성 돌출부위를 파괴하고 섬유화를 심화시키며, 위벽 심 부에 종양이 남게하는 효과가 있다. 조직병리학적 변화를 보면 궤 양형성, 점막 부종, 염증성 침윤, 콜레스테롤 육아종, 괴사등의 변 화는 없으나 종양의 점막이 편평 해지면서 종양의 중앙으로 원심 성의 섬유화를 보이고 광범위한 미만성의 섬유화는 없으며, 종양 기저부 주변에만 잔존종양이 관찰되고 림프절은 결절성 섬유화와 유리질증(hyalinosis)이 나타난다. 그러므로 수술을 시행함에 있 어 미만성 섬유화로 인해 위 절제 범위를 결정하기 힘든 경우는 없기 때문에 위 절제의 일반적 원칙에 따라 충분한 절제연을 확보 하여 위아전절제술 혹은 위전절제술을 각각 시행하고 림프절 절 제술은 D2 또는 D2+a가 권장되는 술식이다. 또한 신뢰도 있는 최적의 연구 결과를 위해 위암 수술의 숙련도가 인정된 외과의사 에 의해 수술이 시행되어야 한다. 추가적으로 치료 효과 판정에 도움이 될 것으로 판단되는 것은 PET-CT를 이용한 대사반응과 병리학적 관해 여부를 비교하는 것과 항암제의 여러 기전에 관련 된 표적 물질의 발현 여부를 치료 전, 후에 비교해 보는 방법이 고 려될 수 있다.

\section{결 론}

위암의 다학제적 치료 개념에서 수술 전 선행화학요법 또는 수 술 전, 후 화학요법이 위암 치료의 표준치료로 정립되기 위해서는 우선 술전 정확한 병기 판정을 위한 노력이 중요하며, 환자에게 가장 적절한 치료 방침을 결정하기 위한 협진 팀제의 운영이 필요 하다. 또한 최근의 3 상 임상연구에서 그 효과가 입증되고 있기는 하나 이러한 연구 결과를 국내에 적용하기에는 적절하지 않으므 로 한국의 실정에 맞는 수술 방법 및 대상 환자를 고려한 대규모 의 3상 임상 연구가 필요하며, 화학요법에 사용될 항암제의 선택 에 있어 종양 반응률, 치료 순응도를 고려한 적절한 항암제의 선 택 및 약제의 개발과 병행하여 향후 위암의 표적치료에 대한 약제 의 연구도 함께 진행되어야 할 것이다.

이러한 노력이 병행되면 선행화학요법이 위암환자의 삶의 질을 높이고 생존율을 향상시킬 수 있는 보다 효과적인 치료요법으로 정립될 수 있을 것으로 기대한다.

\section{REFERENCES}

1. Wilke $H$, Preusser P, Fink U, Gunzer U, Meyer HJ, Meyer J, et al. Preoperative chemotherapy in locally advanced and nonresectable gastric cancer: a phase II study with etoposide, doxorubicin, and cisplatin. J Clin Oncol 1989;7:1318-1326.

2. Kang YK, Choi DW, Im YH, Kim CM, Lee JI, Moon NM, et al. A phase III randomized comparison of neoadjuvant chemotherapy followed by surgery versus surgery for locally advanced stomach cancer. Proc Am Soc Clin Oncol 1996:503a.

3. Sakamoto J. Neoadjuvant chemotherapy: a standard treatment for locally advanced gastric cancer in the future? Gastric Cancer 2003;6:131-133.

4. Hartgrink $H H$, van de Velde $C J$, Putter $H$, Songun I, Tesselaar ME, Kranenbarg EK, et al. Neo-adjuvant chemotherapy for operable gastric cancer: long term results of the Dutch randomised FAMTX trial. Eur J Surg Oncol 2004;30:643-649.

5. Cunningham D, Allum WH, Stenning SP, Thompson JN, Van de Velde CJ, Nicolson $M$, et al. Perioperative chemotherapy versus surgery alone for resectable gastroesophageal cancer. $\mathrm{N}$ Engl J Med 2006;355:11-20.

6. Boige V, Pignon J, Saint-Aubert B, Lasser P, Conroy T, Bouch?et $\mathrm{O}$, et al. Final results of a randimized trial comparing preoperative 5-fluorouracil (F)/cisplatin (P) to surgery alone in adenocarcinoma of stomach and lower esophagus(ASLE): FNLCC ACCORD07-FFCD 9703 trial. Proc Am Soc Clin Oncol 2007;25:4510a.

7. Ajani JA, Mansfield PF, Janjan N, Morris J, Pisters PW, Lynch PM, et al. Multi-institutional trial of preoperative chemoradiotherapy in patients with potentially resectable gastric carcinoma. J Clin Oncol 2004;22:2774-2780.

8. Ajani JA, Mansfield PF, Crane CH, Wu TT, Lunagomez S, Lynch $\mathrm{PM}$, et al. Paclitaxel-based chemoradiotherapy in localized gastric carcinoma: degree of pathologic response and not clinical parameters dictated patient outcome. J Clin Oncol 2005;23:1237-1244. 9. Ajani JA, Winter K, Okawara GS, Donohue JH, Pisters PW, Crane $\mathrm{CH}$, et al. Phase II trial of preoperative chemoradiation in patients with localized gastric adenocarcinoma (RTOG 9904): quality of combined modality and pathologic response. J Clin Oncol 2006;24:3953-3958.

10.Macdonald JS. Treatment of localized gastric cancer. Semin Oncol 2004;31:566-573.

11. Kim YH. Recent trends in the treatment of advanced gastric cancer. Korean J Med 2007;73:123-130.

12. Macdonald JS, Smalley SR, Benedetti J, HundahI SA, Estes NC, Stemmermann GN, et al. Chemoradiotherapy after surgery compared with surgery alone for adenocarcinoma of the stomach or gastroesophageal junction. N Engl J Med 2001;345:725-730. 